\title{
Investments in renewable electricity production: The importance of policy revisited
}

Ingrid Mignon and Anna Bergek

\section{Linköping University Post Print}

\section{Tweet}

N.B.: When citing this work, cite the original article.

Original Publication:

Ingrid Mignon and Anna Bergek, Investments in renewable electricity production: The importance of policy revisited, 2016, Renewable energy, (88), 307-316.

http://dx.doi.org/10.1016/j.renene.2015.11.045

Copyright: Elsevier

http://www.elsevier.com/

Postprint available at: Linköping University Electronic Press

http://urn.kb.se/resolve?urn=urn:nbn:se:liu:diva-125141 


\title{
Investments in renewable electricity production: the importance of policy revisited
}

\author{
Ingrid Mignon ${ }^{\mathrm{a},{ }^{*}}$ and Anna Bergek ${ }^{\mathrm{a}, \mathrm{b}}$ \\ ${ }^{a}$ Department of Management and Engineering, Linköping University, SE- 58183 Linköping, Sweden. \\ ${ }^{*}$ Corresponding author Email: Ingrid.mignon@,liu.se, Tel: +461328 1000 \\ ${ }^{b}$ Centre for Technology, Innovation and Culture (TIK), University of Oslo, P.O. Box 1108 Blindern, N-0317 Oslo, \\ Norway.
}

\begin{abstract}
Finding ways to encourage investments in renewable electricity production is crucial to reach a transition to a sustainable energy system. While in the energy policy literature, investments are usually explained by economic or regulatory policies, recent studies have suggested that some investors are boundedly rational and may respond differently to policies. In this paper, a framework is proposed to make a more complete analysis of the institutional demands influencing emerging investors in renewable electricity production. Based on 35 cases, both formal and informal demands were identified and their impact on emerging investors' behavior was analyzed. Results show that besides formal institutional demands, emerging investors were influenced by their task environment and by various informal demands which originated in investors' collective and internal contexts. However, different investors were affected by different institutional demands. They also responded in different ways to the same demands; while some perceived a specific demand as imposing, others regarded it as inducing. These findings provide a better understanding of the institutional forces affecting emerging investors in renewable electricity. The paper suggests new policies to handle the heterogeneity of investors and opens up for a new panorama of informal policy channels, where network effects can be utilized to trigger emerging investors' decisions.
\end{abstract}

\section{Keywords}

Renewable electricity production, policies, institutional demands, investments, heterogeneity, Sweden

\section{Highlights}

- Both formal and informal institutional demands influence emerging investors in RE production

- Informal institutional demands originate in investors' collective and internal contexts

- Investors are heterogeneous in the way they perceive and react to demands.

- Policies should consider other channels, such as investors' networks, to influence investments. 
In recent years, a large number of actors have invested in renewable electricity (RE) production, ${ }^{1}$ including not only established electricity producers, such as big utilities and municipal or regional energy companies, but also emerging investors such as individuals and households, cooperatives, project developers, farmers and companies diversifying from other industries $[2,3]$. Considering the limits to government investment budgets, such investors are important in order to achieve a transition to a more sustainable energy system [4].

In the energy policy literature, this trend is explained by referring to the energy policy instruments that are in place in many countries today; actors are believed to invest either because economic incentives such as feed-in tariffs or tradable green certificates make RE production competitive with conventional electricity production or because they are forced to invest by renewable performance standards or other types of regulations [e.g. 5]. Among the economic incentives currently used, some are technology-specific (e.g. the feed-in tariffs used in Germany and in France), and other generic, i.e. aimed at all renewable energy technologies (e.g. the tradable green certificate system used in Sweden where certificates are obtained (and traded) by RE producers for each produced MWh).

Although it might seem intuitively reasonable to explain the emergence of new types of RE producers by the presence of energy policies, this explanation only provides part of the picture. According to institutional theory, formal institutions such as economic and regulatory policy instruments are indeed likely to influence actors' investment decisions, but informal institutions such as norms and values matter as well [6]. Norms and values are a result of network and group belonging [e.g. 7] and it is therefore particularly relevant, given the heterogeneity of the emerging investors group with regard to networks and industry belonging, to assume that different informal institutions may affect them. This implies that a complete institutional analysis, including both formal and informal institutions, is needed in order to understand what role current energy policy instruments actually play in the investment decisions of emerging investors.

In this paper, we study emerging investors in RE production in Sweden with the purpose of identifying how their investment decisions were influenced by various formal and informal institutional demands.

\section{Theoretical framework}

\subsection{Economic rationality vs. institutional demands}

Why do firms and other actors invest in RE production and what influences their investment decisions? In the energy economics literature, investors are generally assumed to behave in an economically rational way, i.e. to make a specific investment only if the expected economic return on that investment is positive and higher than on other investments [2]. Similar assumptions are also implicit in much of the energy policy literature, especially in discussions on how to promote RE production, where it is emphasized that $\mathrm{RE}$ production is not yet competitive with conventional energy production and that policy measures to level the playing field therefore is needed to attract investors [4, 8-15]: "no binding targets, no active policies and reliable instruments mean no markets" [5, p. 15].

${ }^{1}$ In line with the Renewable Energy Directive [1], we define renewable electricity production as electricity "from renewable non-fossil sources, namely wind, solar, aerothermal, geothermal, hydrothermal and ocean energy, hydropower, biomass, landfill gas, sewage treatment plant gas and biogases". As will be explained later, all these are, however, not included in the empirical parts of this paper. 
This assumption can, however, be criticized. It has, for example, been argued in previous literature that rationality is "bounded" by informational and cognitive constraints $[16,17]$ and, in consequence, that "perceptions matter" for energy investments [18 p. 6]. More important for the purpose of this paper, it has also been argued that the assumption of economically rational behavior largely ignores the influence of social forces on decision making [19, 20] and neglects the presence and power of other types of institutions than codified regulative elements [21]. These two arguments indicate that a broader perspective is called for in order to understand why and how investors act in relation to RE production.

It is useful to first distinguish the task environment from the institutional environment.[22]. The task environment includes "normal" business aspects related to the development and production of products that actors exchange in the market, e.g. sources of input, markets for outputs and competitors [22]. It primarily exerts demands (or pressures) on actors in the form of requirements on efficiency and effectiveness [22], for example customers bargaining to get higher-quality products or lower prices [23]. Institutional environments, in contrast, include regulations, social norms and social expectations that individuals and organizations have to comply with in order to secure legitimacy, resources and power [6, 24, 25]. Demands from the institutional environment come in the form of prescriptions regarding "the right thing to do" (in a legal, moral or cognitive senses) and the right way to do things (e.g. acceptable types of organizational forms for a particular task [22]) .

In this paper, we are primarily interested in complementing the techno-economic focus of previous energy policy literature by focusing on institutional demands, but at the same time we fully acknowledge that demands from the technical environment matter as well for investments. ${ }^{2}$

\subsection{Institutional demands on investments in RE production}

A main argument of the institutional literature is that even though people and organizations can and do act in their own self-interest and to the purpose of achieving set goals, their behavior is also heavily influenced by internal and external institutions $[6,21,26-28] .^{3}$ Among other things, institutions influence what information people select, how they interpret it and what criteria they use to evaluate different action alternatives [28] and shape perceptions about the potential and limits of technologies, markets and firmspecific capabilities [29] - all which influence investment decisions. Even for economically oriented actors, institutions influence what is considered "an 'appropriate' kind of economic behavior" in a specific time, space and social network [30].

In previous literature, two main sources of institutional demands are emphasized:

- Formal institutions include regulations, laws and other types of policies as well as infrastructural constraints and bureaucratic requirements [21, 28]. They tend to be related to monitoring and sanctioning activities [21] and actors conform to them because they fear punishment or because it is in their self-interest to do so [31, 32].

- Informal institutions include on the one hand values and norms that define what behavior is preferred or considered proper and prescribe how things are to be done $[21,28,31]$, and on the other hand

\footnotetext{
${ }^{2}$ It should also be acknowledged that markets at least to some extent are institutionally constructed [21]

${ }^{3}$ For an extensive literature review, see [6]
} 
cognitive rules, such as cultural frames and routines, which actors use to make meaning of reality [21]. ${ }^{4}$ Actors conform to informal institutions because of a social (or moral) obligation [31, 32], because it is expected of them $[20,21,34]$ or because they cannot think of any other option $[21,34]$.

Judging by previous literature on investments in RE production, formal institutional demands, in the form of various energy policy instruments, are the dominating influence on investors. However, some previous literature also indicates that informal institutional demands might influence actors' decisions to invest in RE production. For example, researchers have found that social interactions, perceptions and expectations have influenced decisions and intentions to adopt PV systems in the US, Germany and Sri Lanka [35-38] and the willingness to pay for microgeneration technologies in Ireland [39]. Other studies have underlined that drivers and motives for investing in RE production differ among emerging investors and that emerging investors are more subjected to informal institutions than more established investors, such as utilities and energy companies [40, 41]. We have, however, not found any studies that consider formal and informal institutional together in order to understand what influences emerging investors' decisions. This leads us to formulate the following research question:

\section{RQ1: What formal and informal institutional demands influence emerging investors in RE production?}

In the literature on formal institutions, in particular energy and environmental policy, it has been highlighted that they can exert two main types of influence. They can either impose potential investors to invest, e.g. by mandatory targets [8] or quota obligations [42], or induce them to do so, e.g. by fixed feed-in prices, price premiums, tradable green certificates, investment subsidies, preferential loans, tax rebates or net metering [42-46]. However, although the environmental policy literature generally seems to have come to the conclusion that economic policy instruments are more effective than regulatory policy instruments in stimulating technology diffusion [47, 48], there is very little knowledge about the impact of informal institutional demands on investments. This is a clear gap particularly in the RE sector, where previous studies have suggested that investors form a heterogeneous group of actors belonging to different institutional contexts, for instance with regard to their individual norms and values [2]. This leads us to formulate the following research question:

\section{RQ2: How do formal and informal institutional demands influence emerging investors in RE production?}

\section{Methodology}

\subsection{Study design}

Because of the explorative purpose of this study, we chose to use a case study method to study the influence of formal and informal institutional demands on emerging investors. Indeed, one of the strengths of case study methodology is that it provides rich empirical data that makes in-depth explorative analysis possible [49]. Moreover, case study research calls attention to the rich real-work context in which the phenomena take place, which is a prerequisite for the study on institutional demands [50]. More specifically, we used a qualitative, embedded case study research design, consisting of a cross-case analysis of 35 emerging investors within the overall case of Sweden.

\footnotetext{
${ }^{4}$ In the institutional literature, a distinction is often made between normative and cognitive institutions. However, in reality "the normative and cognitive dimensions ... are not always easily separated - actors are guided in what they think is right and what they want to do by what they know and are able to do" $[33,577]$
} 
The case of Sweden is relevant for several reasons. First, since May 2003 a TGC system provides economic incentives for investment in renewables such as biomass-based power, hydropower, wind power and solar power. This makes possible the comparison of the influence of a common-to-all economic policy instrument with other potential institutional demands. Second, all RE producers have to apply to the Swedish Energy Agency in order to receive tradable green certificates and data from granted applications are gathered in a publicly available database, which made it possible to identify the actors included in this study.

Despite the advantages of this case, focusing on one specific context may raise questions regarding the generalizability of the findings. For instance, it could be argued that the findings of our study are irrelevant for other institutional contexts. Although we are aware of this potential limitation, which we address further in Section 5, it should be noted that other studies have shown that even in other institutional contexts, e.g. in Germany, the Netherlands and France, emerging investors with similar characteristics with regard to their organizational forms and the share of the RE capability that they own, are present in the RE production market [41, 51].

\subsubsection{A cross-case analysis of 35 emerging investors}

In order to understand the influences of formal and informal institutional demands on the behavior of emerging entrants, we used a cross-case analysis. This method is particularly well suited to clarify people's perceptions, assumptions, prejudgments and predispositions. Indeed, in addition to giving interviewees the freedom to describe their investment process from their own viewpoint instead of forcing them to label it as a predefined process (as e.g. quantitative methods such as survey would have done) [52, 53], it gives the researcher the possibility to observe patterns of behaviors through the discovery of polar types or replicating behaviors [54].

Our starting point for the selection of cases of emerging investors was to identify them within the larger population of investors in RE production available in the TGC database. This was done by excluding energy sector incumbents (i.e. state-owned and privately owned utilities and energy companies) and instead focusing on emerging investors, such as farmers, companies coming from other industrial sectors, associations, public organizations, individuals and independent power producers. Through this process, we found that in July 2012, emerging investors owned about 75 percent of the RE plants in Sweden and about 55 percent of the installed capacity [55].

Once the emerging investors identified in the overall data, cases of emerging investors were selected to provide a variety of contexts with regard to potential task and institutional environments (see Table 1). Since the goal of cross-case analysis is not to reach statistical representativeness of the overall population, but rather to acquire insight into a specific phenomenon and to consider the potential behavioral variation among cases, we continuously added cases in order to increase the analytical power of the data until new information became limited, either because similar responses emerged or because contrary responses emerged for predictable reasons $[50,54,56]$. This process resulted in a cross-case analysis of 35 emerging investors with different characteristics and with investment in different types of RE technologies, as illustrated in Table 1.

\section{INSERT TABLE 1 HERE}


164 Data were collected through semi-structured interviews ${ }^{5}$ with plant owners themselves or with employees who had been actively involved in the investment process for at least one of the investor's RE production plants. Interviewees were asked to describe their investment process in detail, for example when and why the idea of investing appeared, what happened in the context at that time that may have led to the idea, and to motivate every choice made during that process, for example how the technology, suppliers, financing model, etc. were chosen. We did not ask them directly to explain what had influenced them, but we instead encouraged them to describe their process quite freely.

One limitation with qualitative interview methodology is that it leaves room for interpretation of the researcher conducting the study and analysis, as well as perceptions of interviewees answering questions. In the interviews, some respondents may have transformed their answers to match what they thought the researcher expected or they may have selected only the information that they perceived made them look in a better light. In order to reduce the risk of bias interpretation in the analysis, interviews were recorded, transcribed and coding independently by two researchers. We evaluate the risk of distorted answers as low for two reasons. First, the interviewees did not only described the bright side of their investment process, but aspects which, from a purely economic perspective were not rational, and well as aspects which they considered as mistakes. Second, the constituency of patterns obtained through cross-case analysis strengthens the reliability of the findings. Nevertheless, opportunities to make findings more reliable and generalizable represent opportunities for further research, which are discussed in Section 5 of this paper.

The coding was made into two steps. First, the data was coded to identify the sources of demands that influenced investors. As described in Table 2, demands from the task environment and from formal institutions were coded based on descriptions in the literature introduced in Section 2. Institutional demands were coded as informal when they were tacit and came either from the investors' networks or stakeholders or from the investors themselves but were not related to any written or official document. Second, once the sources of demands had been identified, the nature of their influence was coded. Overall, demands were coded as imposing when investors described them as being out of their control, if they did not consider any other option than to invest or if they made the investment unwillingly. Demands were coded as inducing when investors described them as drivers or motivators or when they led actors to invest voluntarily, without being forced to. More details about the coding of different demands and their characteristics can be found in Table 2 and evidence of the coding can be found in the presentation of the data in Table 3.

\section{INSERT TABLE 2 HERE}

\section{The role of institutional demands for investments in renewable electricity production in} Sweden

The interviews show that investors' decisions to invest have been influenced by a number of demands. As discussed previously in the energy policy literature, these demands came both from investors' task environments and from formal institutions. Moreover, as underlined in the institutional literature, investors were also influenced by informal institutions. Interestingly, different forces had different impacts on investors; similar demands were both imposing for some investors and inducing for some others.

\footnotetext{
${ }^{5} \mathrm{On}$ average, each interview lasted 60 minutes. Interviews were recorded and transcribed after the interview.
} 
Finally, it also emerged from the interviews that different forces affected different stages of the investment, i.e. the decision to invest or the investment process. In the coming sections, we analyze these demands and their impact on investment behaviors more in detail. The analysis is based on data collected in the interviews, which are summarized in Table 3.

INSERT TABLE 3 HERE

\subsection{Demands from the task environment}

Some of the interviewed investors reported demands coming from the task environment of their main business activity or from the task environment of renewable electricity. For instance, although it was not intended changes in their stakeholders' strategies led them to evaluate the possibility to start producing renewable electricity (cf. cases 6,12). Likewise, a change in the market lowering or increasing the value of the main resource used in their main activity triggered the decision to invest in renewable electricity (cf. cases $3,9,18)$. In other cases, it was a change in the electricity prices or in the renewable electricity technology prices that were decisive (cf. cases 7 , case 10,15).

As illustrated in Table 2, demands from the task environment were both imposing and inducing for investors' decision. Interestingly, the same type of pressures, for instance an increase in the electricity prices, was both inducing for some investors (e.g. case 10) and imposing for others (e.g. cases 15, 27). Surprisingly, compared with the demands coming from formal and informal institutions described in the following sections, pressures coming from the task environment affected the decision to enter the renewable electricity production, but it did not seem to impact the investment process.

\subsection{Formal institutional demands}

As presented in Table 2, formal demands had a clear impact on the interviewees' investments in renewable electricity production. Similarly to the demands coming from the task environment, formal demands were perceived differently among investors: some described them as imposing, for instance when they felt forced to comply with regulations by investing (e.g. case 17), whereas other described them as inducing, for instance when policies created an incentive to invest (e.g. cases 10, 16, 21, 23, 29 and 32).

Yet, while the energy literature restricts the formal demands to regulatory and economic instruments for renewable energy investments, our study showed that other policy instruments, such as tax exemptions (cf. cases $6,9,10,18,26,27$ ) also played a key role in the decision process. Formal corporate policies, such as a new environmental strategy or new corporate objectives towards sustainability, which can be seen as formal demands at the company level, also had an influence in some cases (cf. cases 12, 13, 18, 21, 24, 30, $35)$.

Another key finding was that formal institutional demands were not only the trigger for some investors' decision (as in cases $6,10,11,12,16-18,21,23,26,27,29,32$ ), but they also affected the investment process. In some cases, for example, it made the decision easier to take or to argue for in the organization (cf. cases 4, 7, 9, 25, 31). In that matter, it should be noted that in many cases, economic policy instruments represented a "bonus", i.e. some extra support that the investors did not expect to get, which lowered the risk of the investment or made it more profitable (cf. cases 4,7 ). 
240 As argued in the institutional literature (but quite overlooked by the energy policy literature), informal institutional demands have been at least as influential - and in many cases even more - as the formal institutional demands. Two main types of informal demands emerged from our interviews: collective and internal.

\subsubsection{Collective informal demands}

Collective demands came from external stakeholders and were often directed towards a responsible environmental or societal behavior, for instance customers requiring environmental-friendly practices. As illustrated in Table 2, some investors chose to start producing renewable electricity because they wanted to match what according to them was what everyone else thought was right (cf. cases1-3, 17, 35) or because they saw it as a way to increase their legitimacy or to improve their image (cf. cases 7-10, 13, 15, 20, 32).

The collective informal demands were both inducing and imposing. Indeed, while some of them saw the decision to invest as a way to comply with norms coming from external stakeholders (cf. cases 1, 6, 17, 23 and 32), some of them saw the opportunity to set the standards towards competitors or in the eyes of their clients, for instance by being among the first companies in their region or in their branch to invest in the technology or take actions towards a better environment (cf. cases 13, 15, 17, 21, 22, 35).

As for the formal demands, collective demands had a dual effect: in some cases, they triggered decisions to invest (e.g. cases 1, 3, 6, 13, 23), whereas in other cases they influenced the investment process once an investment decision had been made (cf. cases $7,16,17,18$ ).

\subsubsection{Internal informal demands}

Internal demands were associated with the investors' internal characteristics, such as what they described as their interest, their values or their beliefs. As illustrated in Table 2, internal pressures were described in terms of an inner motive for investing, such as an interest in technology or a passion or for the environment (cf. cases 9, 11, 14, 16, 22, 28, 31, 35) or in terms of personal aspirations (cf. cases 7, 14, 23 and 26). Many investors were also influenced by their own judgment about what is right or wrong and fair or unfair (cf. cases 1, 3, 4, 6, 14 and 28). In some cases, such internal "ethos" were linked to the investors' personalities, for instance, what they thought was in their nature (cf. cases 3 and 8 ) or how they dealt with investment decisions in general (cf. cases 1, 3).

In general, the internal informal demands were very inducing, which suggests that it is more appropriate to see them as internal driving-forces that motivated investors to choose and pursue their investments. (cf. cases $11,16,22,31,35)$. Nevertheless, these demands were also in a few cases a type of mental barrier that limited their options or that set a frame in what they considered as right or wrong, or as possible or not (cf. cases 1, 3, 4, 6).

Similar to the formal and collective informal demands, internal informal demands sometimes had an impact on the decision to invest (cf. cases 5, 7, 8, 9, 11, 14, 16) and sometimes an impact on the investment process (cf. cases 1, 3). However, while the formal pressures and the informal collective pressures may have triggered investors to invest in the renewable electricity production specifically, our interviews showed that internal informal pressures were either driving forces towards broader investment behaviors, for instance towards sustainable or green investments, or towards very specific investment behaviors, for instance towards one specific technology (cf. cases 11, 16, 31). 
In this paper, we have studied investors in renewable electricity production in Sweden with the purpose of identifying how their investment decisions were influenced by various formal and informal institutional demands.

The first research question was what formal and informal institutional demands influence investors in renewable electricity production. Our analysis shows that although the studied investors were affected by economic policy instruments, such as investment subsidies or the TGC system, government regulation (e.g. energy regulations and tax planning incentives) and formal institutions at the organizational level (e.g. corporate policies and strategic goals) were of equal or larger importance in individual cases. Our findings, thus, confirms the propositions in previous literature that demands from formal institutions matter for investment decisions, but they also to some extent contradict much of the energy policy literature, which tends to argue the general supremacy of economic policy instruments [cf., e.g. 47, 48].

Moreover, the investors in this study were subjected both to collective informal demands (i.e. demands initiated by external stakeholders) and to internal informal demands (i.e. demands associated with investors' individual characteristics, preferences and strategies). This finding not only confirms suggestions made in previous literature that informal institutional demands can play a role for decisions to invest in renewable electricity production [35-38, 57], but also highlights that such demands may come in different forms.

In the second research question, we wondered how formal and informal institutional demands influence investors in renewable electricity production. With regard to this, a first finding in the study was that the investors responded in different ways to the same formal institutional demands. Most notably, while some of them were triggered to invest by economic policy instruments (i.e. formal institutional demands), others were not influenced by them at all. Instead they were triggered by collective or individual informal demands. A second finding was that responses differed between investors even when they were affected by the same demands; while some investors perceived a specific demand as imposing and felt forced to comply with it, other investors regarded it as inducing and felt that it encouraged or facilitated their investment. Together, these two findings indicate that investors are heterogeneous with regard to how they are influenced by formal and informal institutional demands. This contributes to an emerging literature, which emphasizes the heterogeneity among investors [e.g. 2, 18, 58]. Finally, in our study institutional demands did not only have an impact on the investors' decisions to invest in renewable electricity production, but also on how they implemented those decisions, e.g. by inducing or imposing the choice of a specific technology. Our findings, thus, indicate that formal and informal demands do not only have an impact on investment decisions, but may affect the entire investment process.

\subsection{Policy implications}

These conclusions have a number of implications for the choice and design of government policy. First, they confirm the suggestion made in previous research that "an effective policy mix is based on a thorough understanding of investor realities, including cognitive factors, and includes segmentation" [18, p. 6]. Indeed, our study shows that different investors are influenced by different institutional demands, which emphasizes the need of designing a portfolio of several different policies (a 'policy mix') in order to stimulate investments in renewable electricity production. Although some investors respond well to 
current energy policies, the fact that other types of institutional demands (e.g. demands from external stakeholders and internal driving forces) are at least as influential for some investors indicates that the debate about what type of economic incentive system to apply [e.g. 59, 60-62] needs to be broadened to also include discussions about other types of energy policies.

Second, our conclusions highlight the potential of new ways for policy makers to influence investment decisions. While economic incentives and regulations have often been assumed to be the only ways to encourage or compel actors to invest in renewable electricity production, our results show that the power of collective demands (e.g. network norms or image) and of influences from the task environment (e.g. industry changes) are not to be underestimated. This indicates that policy makers should try to use existing regional or industry networks - or even create new network effects - to spread information about investments in renewable electricity production and to develop new norms in favor of such investments.

Finally, the impact of institutional demands on different stages of the investment process shows that even if some investors are not triggered by policies to make the decision to invest, policies may still influence them later in their investment processes. For example, policy makers could improve the quality of investments by implementing policies (e.g. performance standards or information activities) targeted at influencing the size of investment projects, technology choices and other choices made during the investment process in order to make better use of available (locational and financial) resources.

\subsection{Opportunities for further research}

Our research has limitations that also represent opportunities for further research. First, the study included four main RE technologies; wind, hydro, solar and biomass power. It may therefore be questioned whether the results (e.g. with regard to investor constellations and the institutional demands affecting them) would have been different if we only had focused on one technology, e.g. wind power or solar power specifically. We therefore encourage future research to further investigate the investor heterogeneity with RE technologies, for instance by focusing on one specific technology or by comparing investors of one RE technology with those of another RE technology. Likewise, as developed in the methodology section, the study context of the research conducted in this paper is Sweden and, although there are indications that investor constellations may be comparable to other institutional settings, it would still be very relevant to increase the generalization of the findings by adding cases of other countries, e.g. other cases of European countries and cases of countries where no or different energy policies are in place.

Second, also with regards to methodology, we have argued for the relevance of qualitative studies in the explorative stage of the research on institutional demands. Now that this stage has been done and that propositions have been made in the conclusions of this paper, there are opportunities for testing these propositions through quantitative research, e.g. through surveys.

Finally, this study focused on the emerging investors of RE production because of their particular relevance for the energy system transition and because of their potential diversity with regard to institutional demands. Now that this has been done and that our results have confirmed the influence of informal institutional pressures in relation to formal institutional pressures (and governmental policies in particular), there are reasons to wonder whether this may only be the case for emerging investors, or if the more established actors such as utilities may also be affected by additional institutional demands than only governmental policies. We therefore encourage other scholars to further study what influences traditional investors, such as utilities, to make the choices that they make and on what basis. This may be the first 
362 step in sharpening current policies in order to adapt them better to the current formal and informal

363 institutional context.

\section{Acknowledgements}

365 Financial support from the Swedish Energy Agency's AES programme (Project 33685-1) is gratefully 366 acknowledged. 
Table 1. Cases included in the study

\begin{tabular}{|c|c|c|}
\hline Case & Characteristics & Type of renewable \\
\hline Case 1 & Grain mill company & Hydropower \\
\hline Case 2 & Farmer & Wind power \\
\hline Case 3 & Farmer & Wind power \\
\hline Case 4 & Retired consultant within the chemical industry & Wind power \\
\hline Case 5 & Building owner, landlord & Wind power \\
\hline Case 6 & Farmer & Wind power \\
\hline Case 7 & Grocery store & Solar power \\
\hline Case 8 & Farmer & Biogas \\
\hline Case 9 & Tenant association & Solar power \\
\hline Case 10 & Municipality & Wind power \\
\hline Case 11 & Economic association & Wind power \\
\hline Case 12 & Public waste management company & Biogas \\
\hline Case 13 & Furniture retailing company & Wind power \\
\hline Case 14 & Engineer & Hydropower \\
\hline Case 15 & Infrastructure development company & Wind power \\
\hline Case 16 & Wind power producing company & Wind power \\
\hline Case 17 & Pulp and paper manufacturing company & Biogas \\
\hline Case 18 & Pulp and paper manufacturing company & Biogas \\
\hline Case 19 & Farmer & Wind power \\
\hline Case 20 & Wind project developing company & Wind power \\
\hline Case 21 & Public housing company, landlord & Solar power \\
\hline Case 22 & Childrens wear designer and manufacturer & Wind power \\
\hline Case 23 & Farmer & Biogas \\
\hline Case 24 & Public waste management company & Biogas \\
\hline Case 25 & Wind project developing company & Wind power \\
\hline Case 26 & Retired farmer, part-time accountant & Wind power \\
\hline Case 27 & Municipality & Wind power \\
\hline Case 28 & Renewable electricity producing company & Solar power \\
\hline Case 29 & Independent power producing company & Wind power \\
\hline Case 30 & Public waste management company & Biogas \\
\hline Case 31 & Wind project developing company & Wind power \\
\hline Case 32 & Pulp and paper company & Biogas \\
\hline Case 33 & Test center & Solar power \\
\hline Case 34 & Independent power producing company & Wind power \\
\hline Case 35 & Baking company & Wind power \\
\hline
\end{tabular}


Table 2. Description and coding of the constructs

\begin{tabular}{|c|c|c|}
\hline Construct & Source of the demand & Nature of the demand \\
\hline $\begin{array}{l}\text { Task } \\
\text { environment }\end{array}$ & $\begin{array}{l}\text { Actors, standards and practices } \\
\text { present in the business } \\
\text { environment of the investors. } \\
\text { E.g.: formal and informal } \\
\text { industry requirements, } \\
\text { customers, competitors, } \\
\text { market events. }\end{array}$ & $\begin{array}{l}\text { Imposing: Investments are a result of an event out of investors' control } \\
\text { or of a defensive behaviour due to the perception of a threat on their } \\
\text { current business model or activity coming from their business } \\
\text { environment. } \\
\text { Inducing: Investments are perceived as an opportunity or are made } \\
\text { possible due to an event or change coming from investors' business } \\
\text { environment or from the market. }\end{array}$ \\
\hline \multirow[t]{2}{*}{$\begin{array}{l}\text { Formal } \\
\text { institutions }\end{array}$} & $\begin{array}{l}\text { Governmental policy instruments. } \\
\text { E.g. change in regulation, } \\
\text { creation of an incentive policy. }\end{array}$ & $\begin{array}{l}\text { Imposing: Investments are a result of a change in policies, which is } \\
\text { perceived as a burden or an undesired source of expensive by investors. } \\
\text { Inducing: Investments are perceived as an opportunity or are facilitated } \\
\text { due to a change in regulatory or incentive policy. }\end{array}$ \\
\hline & $\begin{array}{l}\text { Corporate policies and strategies. } \\
\text { E.g. change in the corporate } \\
\text { policy, creation of a new } \\
\text { corporate strategy. }\end{array}$ & $\begin{array}{l}\text { Imposing: Investments are a result of a change in policies, which is } \\
\text { perceived as a burden or an undesired source of expensive by investors. } \\
\text { Inducing: Investments are motivated by a company vision or goal } \\
\text { initiated proactively by the investor, as a way to be a leader or initiator } \\
\text { of a social change. }\end{array}$ \\
\hline \multirow[t]{2}{*}{$\begin{array}{l}\text { Informal } \\
\text { institutions }\end{array}$} & $\begin{array}{l}\text { Collective norms, values and } \\
\text { opinion emerging from } \\
\text { investors' closest network. } \\
\text { E.g. neighbours, friends, family } \\
\text { expressing their opinion or } \\
\text { acting in a way that encourages } \\
\text { investors to imitate them. }\end{array}$ & $\begin{array}{l}\text { Imposing: Investments are the result of a strong belief in investors' } \\
\text { network and community that investing is the right thing to do and that } \\
\text { not investing would be irrational. Investors perceive the demand as an } \\
\text { imposed choice. } \\
\text { Inducing: Investments motivated by investors' desire of recognition or } \\
\text { of public attention in their network and communities. Investors do not } \\
\text { perceive the demand as an imposed choice but instead as their } \\
\text { audacious initiative. }\end{array}$ \\
\hline & $\begin{array}{l}\text { Internal values and norms that } \\
\text { are related to the cognitive } \\
\text { identity or culture of investors. } \\
\text { These characteristics that are } \\
\text { loaded with positive or } \\
\text { negative values and appraisal. } \\
\text { E.g. being a family man, a } \\
\text { farmer, an entrepreneur, a risk- } \\
\text { taker. }\end{array}$ & $\begin{array}{l}\text { Imposing: Investments and investment strategies are limited or framed } \\
\text { by internal norms and values, which creates a parallel rationality in } \\
\text { investors' eyes. Investors perceived the demand as imposing but it is so } \\
\text { close to the values and norms, which they identify themselves with, that } \\
\text { they do not even consider going against it. } \\
\text { Inducing: Investors are motivated to invest based on internal norms } \\
\text { and values that create a type of unbeatable rationality in their eyes. } \\
\text { Investors do not perceive the demand as an imposed choice but instead } \\
\text { are proud of being identified with it. }\end{array}$ \\
\hline
\end{tabular}


Table 3. Example quotes categorized according to the influencing demands

\begin{tabular}{|c|c|c|c|c|}
\hline \multirow[t]{2}{*}{ Main type of demand } & \multirow[t]{2}{*}{ Sub-type } & \multirow[t]{2}{*}{ Cases } & \multicolumn{2}{|c|}{ Examples (quotes from interviews) } \\
\hline & & & Imposing demands & Inducing demands \\
\hline Task environment & & $\begin{array}{l}3,6,9, \\
10,12, \\
15,17- \\
19,25, \\
27,32- \\
33\end{array}$ & $\begin{array}{l}\text { "For farmers, the business is about } \\
\text { making as much as possible from the } \\
\text { natural resources that are available to } \\
\text { us" (Case 3) } \\
\text { "A change in strategy at the } \\
\text { company that used to buy the gas that } \\
\text { we produce forced us to evaluate } \\
\text { alternative uses" (case 12) } \\
\text { "We suspected that the electricity } \\
\text { prices were going to go up" (case 15) } \\
\text { "We had to invest in a new boiler } \\
\text { anyway, so it was worth to include } \\
\text { the turbine to be able to produce } \\
\text { electricity in the investment" (case 17) } \\
\text { "The storm Gudrun showed to all } \\
\text { companies in the sector how fragile } \\
\text { our activity was, it was important to } \\
\text { diversify" (case 18) } \\
\text { "We see the investment as a way to } \\
\text { secure our electricity expenses if the } \\
\text { electricity price increases; it is our way } \\
\text { of being independent and safe" (case } \\
27 \text { ) }\end{array}$ & $\begin{array}{l}\text { "The municipality had started to } \\
\text { discuss the design on a map for wind } \\
\text { power places; it was now or } \\
\text { never" (Case 6) } \\
\text { "The technology prices have gone down } \\
\text { over the last years. I wanted to install } \\
\text { solar panels } 12 \text { years ago but at that } \\
\text { time, it was too expensive." (case 7) } \\
\text { "The electricity prices were really high } \\
\text { at the time so it was a relevant } \\
\text { investment" (case 10) } \\
\text { "We knew that it was a profitable } \\
\text { activity and it was a good complement } \\
\text { to farming" (case 19) } \\
\text { "One of the local companies is a solar } \\
\text { cell factory and it wanted to find a } \\
\text { display plant to promote their } \\
\text { technology" (case 33) }\end{array}$ \\
\hline Formal institutional & $\begin{array}{l}\text { Governmental } \\
\text { policy } \\
\text { instruments }\end{array}$ & $\begin{array}{l}4,6-7, \\
10-12, \\
16-18, \\
21,23, \\
25-27, \\
29,31- \\
32,34\end{array}$ & $\begin{array}{l}\text { "A change in the landfill law forced } \\
\text { the company to look at alternatives to } \\
\text { manage the paper waste. Burning it } \\
\text { to produce heat and electricity turned } \\
\text { out to be the best option" (case 17) }\end{array}$ & $\begin{array}{l}\text { "Getting the investment subsidy clearly } \\
\text { contributed to lowering the investment } \\
\text { risk". (case 4) } \\
\text { "Our accountant recommended wind } \\
\text { power as a good investment to get tax } \\
\text { credits" (case 6) } \\
\text { "We would have invested in solar } \\
\text { power anyway but with the investment } \\
\text { subsidy, it even became profitable!" } \\
\text { (case 7) } \\
\text { "Members of our cooperative pay less } \\
\text { taxes on the electricity they use up to } \\
\text { the level of their membership shares" } \\
\text { (case 9) } \\
\text { "We heard that we were able to benefit } \\
\text { from tax reduction for the self-produced } \\
\text { electricity and that triggered the whole } \\
\text { process!" (case 10) } \\
\text { "Thanks to the TGC, the investment } \\
\text { became more or less cost-free for the } \\
\text { municipality; thanks to that, the } \\
\text { decision was easy!" (case 10) } \\
\text { "At that time, the municipal energy } \\
\text { company was encouraging the } \\
\text { development of renewable electricity } \\
\text { production by developing new projects } \\
\text { and selling them without taking a } \\
\text { profit. We did not miss that }\end{array}$ \\
\hline
\end{tabular}


"The TGC made investing in renewable electricity production the best options compared to the other alternatives" (case 12)

"Since profitability is the main driver of the new projects nowadays, it is clear that the TGC as well as the price of the electricity are determinant for the decision to build or not" (case 16)

"The fact that we produce and use the renewable electricity within the company is also good because we use less oil, which means that we produce less $\mathrm{CO} 2$ and therefore that we have to buy less CO2 emission tradings". (case 17)

"The attractiveness of energy savings and energy production was first, in the nineties, the tax savings and in the twothousands, the TGC took over" (case 18)

"What made the investment possible was the 30\% subsidy for sun power" (case 21)

"I don't think that we would have invested without the 30\% investment subsidy" (case 23)

"A lot of the projects would not be developed if it was not for the TGC; they would not break even" (case 25)

"Through my work as an accountant, I knew that it was possible to get tax reduction by investing in wind power" (case 26)

"We started to look at wind power, because we knew it was good for tax planning" (case 27)

"The TGC combined with the high electricity price made it interesting to start a company dedicated to wind power production" (case 29)

"At the time, there was an investment subsidy for wind power, which facilitated the development of our project" (case 31)

"The TGC system provides an opportunity that cannot be ignored; it is both saving money and earning some more on top!" (case 32)

"Since we do not develop any project with a return under $10 \%$, the TGC is often determinant" (case 34)

Corporate 12-13, "The municipality owning of the policies and 18,21 strategies
24,30 , 35 company just took the decision to have all vehicles run on biogas by 2014, we are therefore planning on
"In 2005, the company took the decision to change the energy policy of the company to use $100 \%$ renewable electricity and to make $25 \%$ of energy 


\begin{tabular}{|c|c|c|c|c|}
\hline & & & $\begin{array}{l}\text { upgrading the plant" (case 12) } \\
\text { "We made the investment to follow } \\
\text { the clear strategy line set by the } \\
\text { municipality that owns us" (case 21) } \\
\text { "We have a clear directive from the } \\
\text { municipalities owning the company, } \\
\text { which states that we have to seek to } \\
\text { be one of the leaders in environmental } \\
\text { management of waste"(case 24) } \\
\text { "The company invested in the gas } \\
\text { turbine because the owner directive } \\
\text { stated that one of the business goals } \\
\text { was to make Earth resources last for } \\
\text { a longer time" (case 30) }\end{array}$ & $\begin{array}{l}\text { savings. The investments in wind power } \\
\text { fall within that frame". (case 13) } \\
\text { "Already in the nineties, energy } \\
\text { production has been part of the } \\
\text { corporate strategy" (case 18) } \\
\text { "In 2012, the company decided over a } \\
\text { new sustainable strategy, where an } \\
\text { electricity consumption with 100\% } \\
\text { coming from renewable sources is the } \\
\text { goal" (case 35) }\end{array}$ \\
\hline Informal institutional & Collective & $\begin{array}{l}1-11, \\
13,15- \\
18,20 \\
22-24 \\
32-35\end{array}$ & $\begin{array}{l}\text { "My neighbours and customers kept } \\
\text { saying 'How can you leave the water } \\
\text { run without trying to exploit it?"” } \\
\text { (Case 1) } \\
\text { "This was all my accountant's fault } \\
\text { - He kept telling me about the } \\
\text { advantages of wind power for my } \\
\text { economic situation". (case 6) } \\
\text { "Nowadays, all large companies such } \\
\text { as ours receive huge pressures to save } \\
\text { energy and to be more energy } \\
\text { efficient" (case 17) } \\
\text { "Most of our projects have been } \\
\text { blocked by municipalities. It's a } \\
\text { scandal that they accept the pressures } \\
\text { of lobbies this way" (case 18) } \\
\text { "I would never have invested if my } \\
\text { neighbour badn't done it before and } \\
\text { convinced me to do the same" (case } \\
\text { 23) } \\
\text { "The business has had a bad image } \\
\text { in the nineties because of its energy } \\
\text { intensiveness, it was therefore } \\
\text { important to show to the customers } \\
\text { that the company also cared about the } \\
\text { environment and took action in that } \\
\text { way" (Case } 32 \text { ) }\end{array}$ & $\begin{array}{l}\text { "Here in the area, everyone wants to } \\
\text { produce wind power but only few have } \\
\text { the money and the place" (case 2) } \\
\text { "Everyone who had invested in a } \\
\text { windmill wanted another one; it had to } \\
\text { be good!" (case 3) } \\
\text { "I involved the customers during the } \\
\text { whole development process. Even now, } \\
\text { they can see the electricity production at } \\
\text { the entrance of the shop, and they like } \\
\text { it!" (case } 7 \text { ) } \\
\text { "Now that I have built the biogas } \\
\text { plant, everyone knows who I am" (case } \\
8 \text { ) } \\
\text { "Our members also feel happy that this } \\
\text { area of the city, which often receives } \\
\text { negative attention, suddenly receive } \\
\text { credit from the media for its } \\
\text { contribution to the environment" (case } \\
\text { 9) } \\
\text { "The municipality has an } \\
\text { environmental-friendly profile, which fit } \\
\text { well with the investment" (case 10) } \\
\text { "What motivated the investment was } \\
\text { the possibility of improving the } \\
\text { corporate image while making a profit" } \\
\text { (case } 13 \text { ) } \\
\text { "We want to lead the way" (case } 13 \text { ) } \\
\text { "We want to be the greenest option in } \\
\text { the building sector" (case 15) } \\
\text { "We feel a responsibility towards our } \\
\text { local community" (case 17) } \\
\text { "Having our own wind mills is a } \\
\text { strong signal for our clients; it has to do } \\
\text { with credibility" (case 20) } \\
\text { "We are part of a consortium of } \\
\text { companies within the same branch on } \\
\text { the regional level and together, we have } \\
\text { decided to make 20\% energy savings" } \\
\text { (case } 21 \text { ) } \\
\text { "We want to be a company that makes } \\
\text { a difference in society"(case 22) }\end{array}$ \\
\hline
\end{tabular}




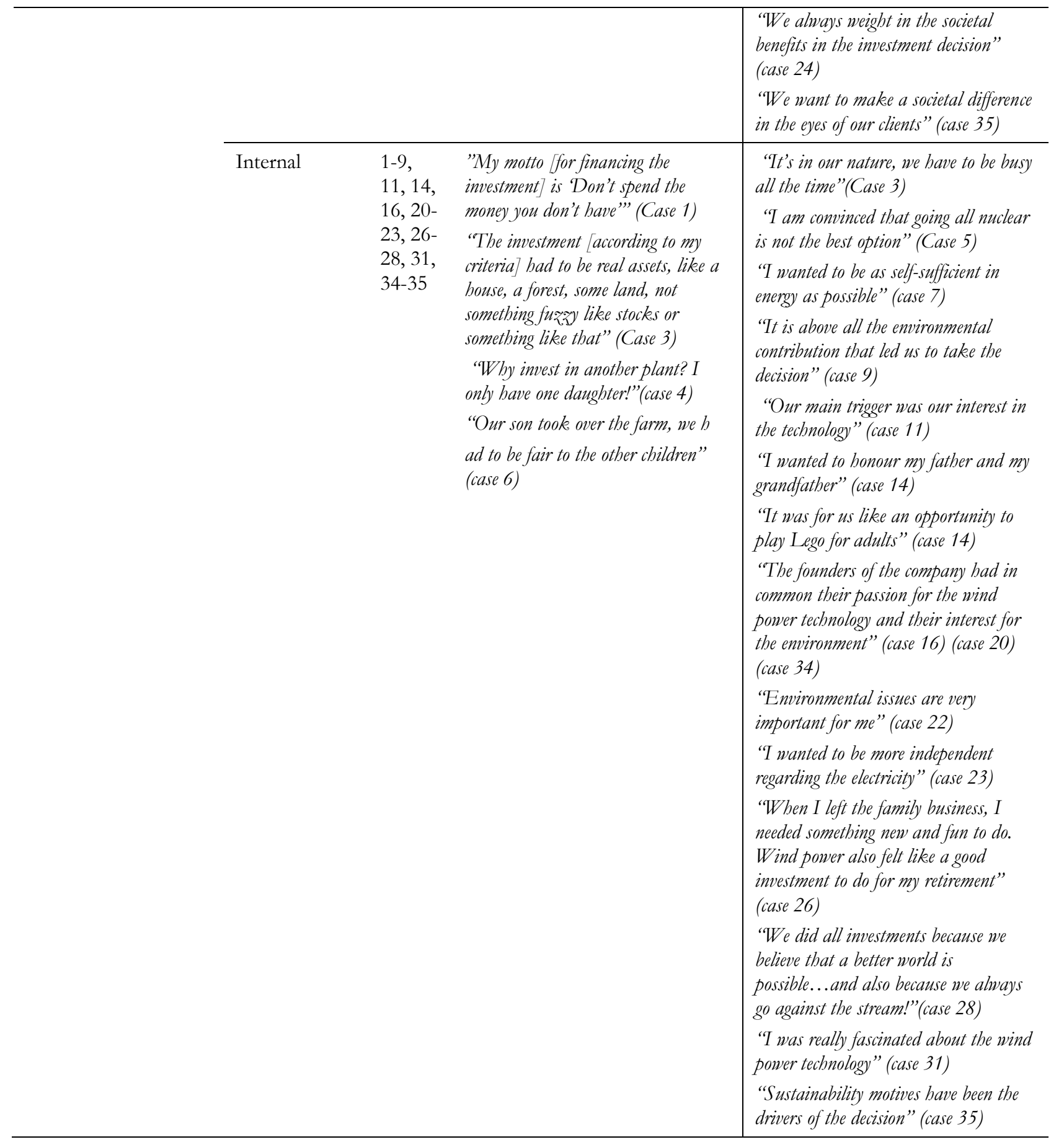

[1] Directive 2009/28/EC of the European Parliament and Council on the promotion of the use of energy from renewable sources and amending and subsequently repealing Directives 2001/77/EC and 2003/30/EC, OJ L 140, 5.6.2009, p. 16-62.

[2] A. Bergek, I. Mignon, G. Sundberg, Who invests in renewable electricity production? Empirical evidence and suggestions for further research, Energy Policy, 56 (2013) 568-581.

[3] O. Langniss, Instruments to foster renewable energy investments in Europe a survey under the financial point of view, Renewable Energy, 9 (1996) 1112-1115. 
[4] C.W. Lee, J. Zhong, Financing and risk management of renewable energy projects with a hybrid bond, Renewable Energy, 75 (2015) 779-787.

[5] D. Fouquet, Policy instruments for renewable energy - From a European perspective, Renewable Energy, 49 (2013) 15-18.

[6] L.G. Zucker, Institutional Theories of Organization, Annual Review of Sociology, 13 (1987) 443-464. [7] D. Wicks, Institutionalized Mindsets of Invulnerability: Differentiated Institutional Fields and the Antecedents of Organizational Crisis, Organization Studies (Walter de Gruyter GmbH \& Co. KG.), 22 (2001) 659 .

[8] L. Byrnes, C. Brown, J. Foster, L.D. Wagner, Australian renewable energy policy: Barriers and challenges, Renewable Energy, 60 (2013) 711-721.

[9] P.D. Lund, Effects of energy policies on industry expansion in renewable energy, Renewable Energy, 34 (2009) 53-64.

[10] F. Pettersson, P. Söderholm, The diffusion of renewable electricity in the presence of climate policy and technology learning: The case of Sweden, Renewable and Sustainable Energy Reviews, 13 (2009) 2031-2040.

[11] P. Söderholm, G. Klaassen, Wind Power in Europe: A Simultaneous Innovation-Diffusion Model, Environmental and Resource Economics, 36 (2007) 163-190.

[12] A.M. Khan, Entrepreneur characteristics and the prediction of new venture success, Omega, 14 (1986) 365-372.

[13] R. Madlener, G. Kumbaroğlu, V.Ş. Ediger, Modeling technology adoption as an irreversible investment under uncertainty: the case of the Turkish electricity supply industry, Energy Economics, 27 (2005) 139-163.

[14] R. Haas, G. Resch, C. Panzer, S. Busch, M. Ragwitz, A. Held, Efficiency and effectiveness of promotion systems for electricity generation from renewable energy sources - Lessons from EU countries, Energy, 36 (2011) 2186-2193.

[15] L. Butler, K. Neuhoff, Comparison of feed-in tariff, quota and auction mechanisms to support wind power development, Renewable Energy, 33 (2008) 1854-1867.

[16] H.A. Simon, A Behavioral Model of Rational Choice, The Quarterly Journal of Economics, 69 (1955) 99-118.

[17] P.P.M.A.R. Heugens, M.W. Lander, Structure! Agency! (and other quarrels): A meta-analysis of institutional theories of organization, Academy of Management Journal, 52 (2009) 61-85.

[18] R. Wüstenhagen, E. Menichetti, Strategic choices for renewable energy investment: Conceptual framework and opportunities for further research, Energy Policy, 40 (2012) 1-10.

[19] M. Granovetter, Economic Action and Social Structure: The Problem of Embeddedness, American Journal of Sociology, 91 (1985) 481-510.

[20] C.E. Clark, E.P. Crawford, Influencing Climate Change Policy, Business \& Society, 51 (2012) 148175.

[21] W.R. Scott, Institutions and Organizations, Sage Publications, Thousand Oaks, 1995.

[22] W.R. Scott, Organizations. Rational, Natural, and Open Systems, 3rd ed., Prentice-Hall Inc., Engelwood Cliffs, N.J., 1992.

[23] M.E. Porter, Competitive strategy: Techniques for analyzing industries and competitors, The Free Press, New York, 1980.

[24] P.J. DiMaggio, W.W. Powell, The Iron Cage Revisited: Institutional Isomorphism and Collective Rationality in Organizational Fields, American Sociological Review, 48 (1983) 147-160.

[25] C. Oliver, Strategic responses to institutional processes, Academy of Management Review, 16 (1991) 145-179.

[26] A. Parkhe, Institutional environments, institutional change and international alliances, Journal of International Management, 9 (2003) 305-316.

[27] C. Oliver, Sustainable Competitive Advantage: Combining Institutional and Resource-Based Views, Strategic Management Journal, 18 (1997) 697-713.

[28] K.A. Munir, Being Different: How Normative and Cognitive Aspects of Institutional Environments Influence Technology Transfer, Human Relations, 55 (2002) 1403-1428.

[29] D.L. Levy, A. Kolk, Strategic Responses to Global Climate Change: Conflicting Pressures on

Multinationals in the Oil Industry, Business \& Politics, 4 (2002) 275-300. 
[30] P.S. Tolbert, R.J. David, W.D. Sine, Studying Choice and Change: The Intersection of Institutional Theory and Entrepreneurship Research, Organization Science, 22 (2011) 1332-1344.

[31] D. Wicks, Institutionalized Mindsets of Invulnerability: Differentiated Institutional Fields and the Antecedents of Organizational Crisis, Organization Studies, 22 (2001) 659-692.

[32] A.J. Hoffman, Institutional evolution and change: Environmentalism and the US chemical industry, Academy of Management Journal, 42 (1999) 351-371.

[33] A. Bergek, S. Jacobsson, B.A. Sandén, 'Legitimation' and 'development of positive externalities': Two key processes in the formation phase of technological innovation systems, Technology Analysis and Strategic Management, 20 (2008) 575-592.

[34] R. Karakaya, The Internet and citizen participation: How institutional environments impacts upon the strategy of a local authority?, in: European Consortium for Political Research General Conference, Marburg, 2003.

[35] B. Bollinger, K. Gillingham, Peer Effects in the Diffusion of Solar Photovoltaic Panels, Marketing Science, 31 (2012) 900-912.

[36] M. McEachern, S. Hanson, Socio-geographic perception in the diffusion of innovation: Solar energy technology in Sri Lanka, Energy Policy, 36 (2008) 2578-2590.

[37] M. Graziano, K. Gillingham, Spatial patterns of solar photovoltaic system adoption: the influence of neighbors and the built environment, Journal of Economic Geography, (2014).

[38] L. Korcaj, U.J.J. Hahnel, H. Spada, Intentions to adopt photovoltaic systems depend on homeowners' expected personal gains and behavior of peers, Renewable Energy, 75 (2015) 407-415.

[39] M.C. Claudy, C. Michelsen, A. O'Driscoll, The diffusion of microgeneration technologies - assessing the influence of perceived product characteristics on home owners' willingness to pay, Energy Policy, 39 (2011) 1459-1469.

[40] K. Hockerts, R. Wüstenhagen, Greening Goliaths versus emerging Davids — Theorizing about the role of incumbents and new entrants in sustainable entrepreneurship, Journal of Business Venturing, 25 (2010) 481-492.

[41] S. Agterbosch, W. Vermeulen, P. Glasbergen, Implementation of wind energy in the Netherlands: the importance of the social-institutional setting, Energy Policy, 32 (2004) 2049-2066.

[42] C.W. Lee, J. Zhong, Top down strategy for renewable energy investment: Conceptual framework and implementation, Renewable Energy, 68 (2014) 761-773.

[43] J. Paska, T. Surma, Electricity generation from renewable energy sources in Poland, Renewable Energy, 71 (2014) 286-294.

[44] B. Msimanga, A.B. Sebitosi, South Africa's non-policy driven options for renewable energy development, Renewable Energy, 69 (2014) 420-427.

[45] P.M. Connor, L. Xie, R. Lowes, J. Britton, T. Richardson, The development of renewable heating policy in the United Kingdom, Renewable Energy, 75 (2015) 733-744.

[46] A. Aslani, K.-F.V. Wong, Analysis of renewable energy development to power generation in the United States, Renewable Energy, 63 (2014) 153-161.

[47] A.-K. Bergquist, K. Söderholm, H. Kinneryd, M. Lindmark, P. Söderholm, Command-and-control revisited: Environmental compliance and technological change in Swedish industry 1970-1990, Ecological Economics, 85 (2013) 6-19.

[48] A.B. Jaffe, R.G. Newell, R.N. Stavins, Environmental Policy and Technological Change, Environmental and Resource Economics, 22 (2002) 41-69.

[49] R. Yin, K, Case study research: Design and methods, 2nd ed., 1994.

[50] K.M. Eisenhardt, M.E. Graebner, Theory building from cases: opportunities and challenges, Academy of management journal, 50 (2007) 25-32.

[51] A. Bergek, I. Mignon, Nya investerare i förnybar elproduktion: motiv, investeringskriterier och policykonsekvenser (NyEL), in: Final report for the project 33685-1, Linköpings Universitet, Energimyndigheten, 2014.

[52] M.Q. Patton, Qualitative evaluation and research methods, SAGE Publications, Inc, 1990.

[53] M. Van Manen, Linking ways of knowing with ways of being practical, Curriculum inquiry, 6 (1977) 205-228.

[54] K.M. Eisenhardt, Building Theories from Case Study Research, Academy of Management Review, 14 (1989) 532-550. 
[55] A. Bergek, I. Mignon, G. Sundberg, Who invest in renewable electricity production? Empirical evidence and suggestions for further research, Energy Policy (2013) 568-581.

[56] K.M. Eisenhardt, L.J. Bourgeois, Politics of strategic decision making in high-velocity environments: Toward a midrange theory, Academy of management journal, 31 (1988) 737-770. [57] R.P.J.M. Raven, Towards alternative trajectories? Reconfigurations in the Dutch electricity regime, Research Policy, 35 (2006) 581-595.

[58] A. Masini, E. Menichetti, The impact of behavioural factors in the renewable energy investment decision making process: Conceptual framework and empirical findings, Energy Policy, 40 (2012) 28-38. [59] S. Jacobsson, A. Bergek, D. Finon, V. Lauber, C. Mitchell, D. Toke, A. Verbruggen, EU renewable energy support policy: Faith or facts?, Energy Policy, 37 (2009) 2143-2146. [60] P. Sun, P.-y. Nie, A comparative study of feed-in tariff and renewable portfolio standard policy in renewable energy industry, Renewable Energy, 74 (2015) 255-262. energy investment, Energy Policy, 38 (2010) 955-965. Energy, 87, Part 1 (2016) 42-53. 